\title{
DISTRIBUTION AND EXPRESSION OF STRIPED CATFISH (Pangasionodon hypophtalmus) GROWTH HORMONE GENE (PhGH) IN THE ORGAN OF AFRICAN CATFISH (Clarias gariepinus) TRANSGENIC FOUNDER
}

\author{
Huria Marnis”, Raden Roro Sri Pudji Sinarni Dewi, Imron, and Bambang Iswanto \\ Research Institute for Fish Breeding, Sukamandi, West Java \\ (Received 10 January 2012 ; Accepted 27 April 2012)
}

\begin{abstract}
Faster growing African catfish can be produced by transgenesis. This study was conducted to investigate the distribution and expression of growth hormone gene (PhGH) in various organs of the transgenic African catfish (Clarias gariepinus) founder $\left(F_{0}\right)$. Transgene was detected using the PCR method in various organs, namely pituitary, brain, liver, heart, spleen, kidney, intestine, stomach, muscle, caudal fin, gill and eye. Transgene expression levels were analyzed using the method of reverse transcriptase- polymerase chain reaction (RT-PCR), $\beta$-actin gene used as internal controls. The results showed that the PhGH was detected and expressed in all organs of the transgenic African catfish founder. The high level of $\mathrm{PhGH}$ expression was found in the liver, pituitary, intestine and brain; smaller amounts were detectable in muscle, spleen, kidneys, heart, and stomach, caudal fin, gill and eyes, range from 0.02- 0.75 PhGH/ $\beta$ - actin mRNA. The expression levels of PhGH had positive correlation with tissue and body size $(\mathrm{P}<0.05)$.
\end{abstract}

KEYWORDS: gene expression, transgenic, growth hormone, Clarias gariepinus, RT- PCR

\section{INTRODUCTION}

Catfish is one of the potential aquaculture commodity in Indonesia, specifically African catfish, Clarias gariepinus. The total production of this species reached 242,811 tons in 2010 (FAO, 2012). Developing the catfish farm is expected to enhance the catfish industry and increases the national fishery product in the future. Improved genetic quality of both fish broodstock and seeds is considered as important components to support the achievement of the target. Genetic improvement through transgenic is one method that can be used to increase aquaculture productivity.
Transgenesis involves genomic alteration of an organism through insertion, modification or deletion of a gene with the objective of modifying characteristics of interest (Carter, 2004). In this manner, new stable and genetically determined characteristics can be incorporated into the genome of the receptor organism and possibly transmitted to the next generations. In the last two decades, this technology was successfully applied in fish due to the fact that these inferior vertebrates present reproductive and biological characteristics that allow easy manipulation of their genetic and physiological processes in the early stages

\# Corresponding author. Research Institute for Fish Breeding JI. Raya 2 Sukamandi, Subang 41256, West Java, Indonesia. Telp.: +62 260520500

E-mail address: huria_marnis@yahoo.com 
of ontogenesis (Zhu \& Shu, 2000). However, genetically modified fish have also been developed as experimental models for fish breeding research, specially in studies increasing aquaculture productivity using growth hormone gene transfer. Several transgenic fish have been successfully produced (Zhang et al., 1990; Du et al., 1992; Rahman \& Maclean, 1992; Devlin et al., 1995; Rahman et al., 1998; Nam et al., 2001; Kobayashi et al., 2007). Growth hormone transgenes of fish origin have universally been shown to be more effective in growth enhancement than those of non-fish origin (Devlin et al., 1995). Growth hormone, produced by the hypothalamus- pituitary- adrenal (HPA) axis, is a pleiotropic hormone regulating many aspects of fish physiology, including growth (Donaldson et al., 1979), osmoregulation (Sakamoto et al., 1997), and reproduction (Trudeau, 1997).

The transgenic technology producing faster growing catfish has been started since 2008 in Indonesia by microinjection (Gusrina et al., 2009). The microinjection was used to produce transgenic fish. It almost invariably produces mosaic fish due to delayed transgene integration, which occured only after a few cycles of embryonic cell division (Figueiredo et al., 2007). However microinjection method used on catfish embryo has a weakness among others, required a high level of skill in the application. The injected eggs were often broken and attached to the needle of microinjection, and the number of embryos that successfully hatched and lived to become adults were very low compared to number of eggs produced fish so the chances of getting the broodstock are able to transmit the transgene at very low on the next generation (Stuart \& Westerfield, 1988).

Nowadays, an alternative way of expressing transgenes in fish has been developed using electroporation to introduce transgenes into the male germ cells. This method has been developed to increase the efficiency of transgene integration or to produce a large number of transformed individuals simultaneously. The electroporation method has been successfully performed to express the transgene in sperm cells and is capable of producing a number of individuals in the same time (Powers et al., 1992).

Early studies were conducted with GH gene transfer in the African catfish. Gene con- structs used were "all fish" GH gene of striped catfish (PhGH) and $\beta$-actin promoter from carp (pCcBA) using the method of sperm electroforation which acted as carriers of the transgene. Transgenic fish were produced by fertilizing wild-type eggs with sperms collected from transgenic African catfish containing the pCcBA- PhGH. The results showed that growth effects can be observed, 2-fold relative to controls (Dewi et al., 2011). The growth effect of transgenic African catfish founder has been due to the distribution and over expression of PhGH gene. The aim of this research is to evaluate distribution and expression PhHG growth hormone gene in transgenic African catfish organs.

\section{MATERIALS AND METHOD}

\section{Animal and Sample Collection}

Three of transgenic fish (founder) and three of non transgenic fish were analyzed in order to detect of PhGH in all tissue. The transgenic founders $\left(F_{0}\right)$ African catfish (8 month of age) carrying the pCcBA- PhGH construct were generated by electroporation with $100 \mu \mathrm{g} / \mathrm{ml}$ of the construct. All fish were derived from a single family of African catfish (Clarias gariepinus) and originated from the collection in Research Institute for Fish Breeding, Indonesia.

\section{Detection and Distribution PhGH All Organs \\ DNA Extraction}

Genomic DNA of each individual tissue sample was extracted using DNA extraction kit following the protocols recommended by manufacturer (GeneJet Genomic DNA Purification, Thermo Scientific). Briefly, the protocol consists of series of steps including Cell lysis, DNA precipitation, binding DNA to the column, washing and elution. Cell lysis was performed by weighing of approximately $10 \mathrm{mg}$ of tissue sample and mincing it with a surgical blade into small pieces. The tissue was lysed by adding $180 \mu \mathrm{L}$ of lysis digestion buffer, $20 \mu \mathrm{l}$ of proteinase $\mathrm{K}$, followed by incubation in $56^{\circ} \mathrm{C}$ for 2 hours and adding $20 \mu \mathrm{L}$ of RNase A solution followed by incubation in room temperature for $10 \mathrm{~min}$. The lysate was added $200 \mu \mathrm{l}$ with lysis solution followed by vortexing for 15 second. The lysate DNA was then precipitated by adding $400 \mu \mathrm{L}$ of $50 \%$ ethanol. Binding DNA to the column was carried out by spinning the mixture lysate DNA and ethanol at $6,000 \times \mathrm{g}$ 
for $1 \mathrm{~min}$. The column binding DNA was then washed twice by adding $500 \mu \mathrm{L}$ of washing buffer I and washing buffer 2 followed by spinning at 8,000 $\mathrm{xg}$ for $3 \mathrm{~min}$ and $12,000 \times \mathrm{g}$ for 3 min, respectively. Finally, the DNA bound to the column was then eluted by adding $200 \mu \mathrm{L}$ elution buffer, incubating it for $2 \mathrm{~min}$ in room temperature and terminated by spinning it at $8,000 \times \mathrm{g}$ for $1 \mathrm{~min}$. To check the success of genomic DNA extraction process, the sample was run on mini horizontal gel electrophoresis. The sample was loaded in to the $1.5 \%(\mathrm{w} / \mathrm{v})$ agarose gel, powered with 65 volt electricity and run for 50 minutes. The gel was then stained with ethidium bromide $(0.5 \mu \mathrm{g} / \mathrm{mL})$ and viewed using gel documentation system ultraviolet transillumination.

\section{Polymerase Chain Reaction (PCR)}

Amplification of PhGH was performed using thermal cycling system (mycycler, Biorad). PCR standard was performed in a final volume of $25 \mu \mathrm{L}$, using a comersial kit master mix faststart PCR master (Roche, Germany). The PCR was used to amplify a 390-bp fragment with primers PhGH1-F (5'- TAG AGT GTT GGT GGT GCT CTC TGT - 3') and PhGH2- R (5'- CGA TAA GCA CGC CGA TGC CCA TTT- 3'), for 35 cycles: denaturing at $94^{\circ} \mathrm{C}$ for 30 secs, annealing at $53^{\circ} \mathrm{C}$ for 30 secs, and extension at $72^{\circ} \mathrm{C}$ for 1 $\mathrm{min}$. The amplification using the specific primer $\beta$ - actin for internal control : bact- $F\left(5^{\prime}\right.$ - TAT GAA GGT TAT GCT CTG CCC- 3') and bact- R ( $5^{\prime}$ - CAT ACC CAG GAA AGA TGG CTG- 3') were designed from a catfish growth hormone sequence. The reaction was incubated at $94^{\circ} \mathrm{C}$ for 30 secs, annealing at $48^{\circ} \mathrm{C}$ for 30 secs, and extension at $72^{\circ} \mathrm{C}$ for $1 \mathrm{~min}$ for $30 \mathrm{cycle}$ and the PCR products separated on $1.5 \%(\mathrm{w} / \mathrm{v})$ agarose gel stained with ethidium bromide $(0.5 \mu \mathrm{g} / \mathrm{mL})$ and visualized by ultraviolet transillumination.

\section{Analysis Expression of PhGH}

\section{RNA Extraction}

Total RNA was extracted from pituitary, brain, liver, heart, spleen, kidney, intestine, stomach, muscle, gill and eye from three transgenic and three non transgenic fish using animal RNA extraction kit following the protocols recommended by manufacturer (Tri Reagent Molecular Research Center, Inc., Cincinnati, $\mathrm{OH}$, USA). Briefly, a small amount of fresh tissue was homogenized in Tri- Reagent RNA (1 mL per 50- $100 \mathrm{mg}$ tissue) followed by incu- bation for 5 mins at room temperature. After added $100 \mu \mathrm{L}$ bromochloropropane per $1 \mathrm{~mL}$ Tri Reagent followed by shake 15 secs, incubated for 15 mins at room temperature and spinning $12,000 \times \mathrm{g}$ for $15 \mathrm{mins}$ at $4^{\circ} \mathrm{C}$. The aqueous phase was collected and precipitated with 0.4 volumes of isopropanol and stored at $4^{\circ} \mathrm{C}$ for $5 \mathrm{~min}$. The precipitated RNA was washed with $1 \mathrm{~mL} 75 \%$ ethanol and resuspended in 200 $\mu \mathrm{L}$ RNAsecure (Ambion) and heated at $60^{\circ} \mathrm{C}$ for 10 mins. Total RNA was diluted to $1.0 \mathrm{mg} / \mathrm{mL}$ in RNase- free water. For synthesizing 1st-strand cDNA, $50 \mu \mathrm{g}$ of total RNA was treated with commersial kit cDNA Ready- To- Go ${ }^{\mathrm{TM}}$ RT- PCR Beads (GE Healthcare) according to the protocol suggested by the manufacturer and 1 Oligo $\mathrm{d}(\mathrm{T})_{16}$ primer (Roche, Germany) in a final volume of $33 \mu \mathrm{L}$.

\section{Reverse Transcriptase- Polymerase Chain Reaction (RT- PCR)}

RT- PCR was performed using thermal cycling system (mycycler, Biorad). The RT- PCR was formed to detect exogenous DNA PhGH in pituitary, brain, liver, heart, spleen, kidney, intestine, stomach, muscle, gill and eye. Two microliter CDNA was used as a templete for RTPCR and then mixed with $1 \mu \mathrm{L}$ primers PhGH- $F$ (5'- TAG AGT GTT GGT GGT GCT CTC TGT - 3') and PhGH2- R (5'- CGA TAA GCA CGC CGA TGC CCA TTT- 3'), for 35 cycles: denaturing at $94^{\circ} \mathrm{C}$ for 30 secs, annealing at $53^{\circ} \mathrm{C}$ for 30 secs, and extension at $72^{\circ} \mathrm{C}$ for $1 \mathrm{~min}$ which produce a $390 \mathrm{bp}$ PhGH fragment but does not amplify the endogenous African catfish growth hormone gene and using cDNA $\beta$ - actin as an internal control. PCR products were separated on $1.5 \%(\mathrm{w} / \mathrm{v})$ agarose gel stained with ethidium bromide $(0.5 \mu \mathrm{g} / \mathrm{mL})$ and visualized by ultraviolet transillumination.

\section{Semiquantitative Analysis of RT-PCR Products}

Semiquantitative analysis was done according to the method described by Laing et al. (Laing et al., 2001). In order to adopt a more semiquantitative approach to analyze exogen PhGH gene expressions, both exogenous $\mathrm{PhGH}$ genes and $\beta$ - actin genes were amplified using a series of cycle numbers (21-30). Following this procedure, for each gene under analysis, the optimal cycle number (do not reach plateau) was determined and subsequently employed in the above expression analysis. After determining the optimal cycle 
number, specific PCR was conducted three times. PhGH genes (25 cycles)/ $\beta$-actin (25 cycles) ratio was determined by using Total Lab $^{\text {TM }}$ 1D 21 CFR v12 software (Total Lab Ltd, United Kingdom).

\section{Statistical Analysis}

Values for mRNA are expressed as means $\pm S D$. The statistical significance was determined by correlation expression PhGH with organs and bodies size SPPS vers. 16. Statistical significance was set at $P<0.05$.

\section{RESULTS AND DISCUSSION}

\section{Detection and Distribution PhGH in All Tissue}

Detection of PhGH in all organs was shown in Figure 1.

All transgenic fish were found to have transgene PhGH in all tissue (392 bp). However non transgenic only detected endogenous gene (600 bp). Exogenous (GH) gene was detected and distributed in pituitary, liver, kidney, skin, intestine, stomach, muscle, spleen, pyloric caeca in fish coho salmon (Mori \& Devlin, 1998), liver, gills, hearth, brain, skeletal muscle, kidney, spleen, intestine and testes in Tilapia (Caelers et al., 2005), eye and brain in salmon (Devlin et al., 2012).

\section{Analysis Expression of PhGH in Various Organs}

Analysis of transgenic fish by reverse transcriptase- Polymerase Chain Reaction (RT- PCR) revealed that transgene could be detected in pituitary, brain, liver, heart, spleen, kidney, intestine, stomach, muscle, caudal fin, gill and eye (Figure 2). As expected, no band of transgene origin was amplified from mRNA non transgenic organs, indicating that no transgene PhGH expressed in non transgenic organs.

We found that all transgenic founder detected and expressed PhGH gene to all examined tissue, indicating that PhGH were integrated into sperm cell. The integration exogenous in the sperm genome due to the internalized exogenous sequences reach the nuclear scaffold of sperm cells; therein, they were subjected to rearrangement(s) mediated by endogenous nucleases and undergo recombination events that eventually caused their integration in the sperm genome
(Spadafora, 2008). Integration in the host genome is rarely under these conditions, and so far it has only been claimed by medaka transgnic fish (Thermes et al., 2002).

PhGH expression level in transgenic founder of African catfish organ was analyzed by semi quantitatif PCR. Expression PhGh in liver is higher than another organs (Figure 3). Organ in transgenic catfish are heavier than non transgenic, indicate that over expression $\mathrm{PhGH}$ in transgenic African catfish organs $(\mathrm{P}<0.05)$ (Figure 4). High concentrations of $\mathrm{GH}$ hormone in the fish body will induce the synthesis of IGF- I in the liver and therefore it stimulates the muscles to synthesize protein. In addition to affecting the secretion of IGF- I, GH hormone can also directly stimulates the muscles to synthesize protein. This factor is thought to cause some transgenic individuals to have larger body and organ size than nontransgenic (Caelers et al., 2005).

No mosaicism PhGH gene was detected in organs from transgenic African catfish founder, PhGH gene was expressed in all organs with different levels. In theory, if all the germ cells of a transgenic fish contained transgene (i.e. no germ cell mosaicism) and this fish was mated with a wild- type fish, $50 \%$ of the offspring would expression the transgene (Stuart \& Westerfield, 1988).

The GH expresion from all tissue was classified according to their $\mathrm{GH}$ expression patterns Gibbs and Schmale (Gibbs \& Schmale, 2000; Thermes et al., 2002) as follows: weak = few cells expressing $\mathrm{GH}$; moderate = less than $50 \%$ of the body expressing $\mathrm{GH}$; or strong = more than $50 \%$ of the body expressing $\mathrm{GH}$. Further studies examining the developmental profiles of expression are required to determine whether a correlation exists between transgene expression and growth rate.

\section{CONCLUSION}

PhGH gene was detected and distributed in all organs of transgenic African catfish founder. Highest level of PhGH gene expression was found in the liver. The expression of PhGH showed correlation between levels of expression PhGH and size of organ and body.

\section{ACKNOWLEGEMENTS}

Thanks to Romy Suprapto and Narita Syawalia for your contribution. 

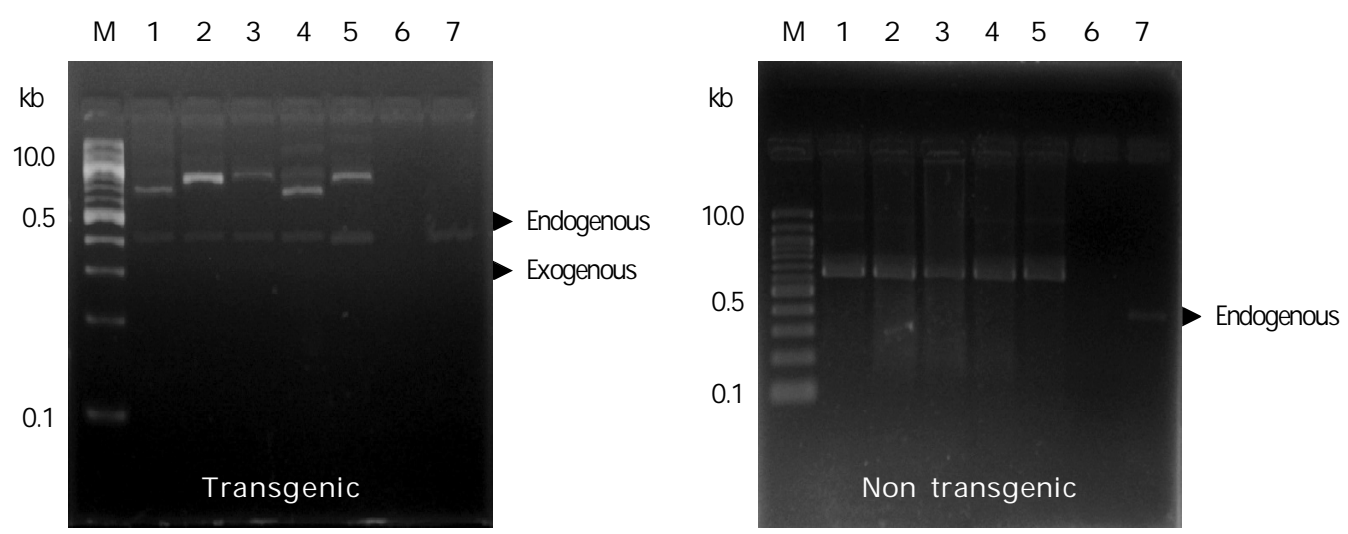

Figure 1. Detection PhGH in several tissues from transgenic African catfish founder $\left(\mathrm{F}_{0}\right)$. Brain (1), pituitary (2), muscle (3), intestine (4), liver (5), negative control (6), positive control (7). M indicates a DNA marker (0.1- $10.0 \mathrm{~kb}$, Vivantis). The expected size of exogenous $\mathrm{PhGH}$ the amplified fragment is $392 \mathrm{bp}$

$\begin{array}{lllllllllllllll}M & 1 & 2 & 3 & 4 & 5 & 6 & 7 & 8 & 9 & 10 & 11 & 12 & 13 & 14\end{array}$

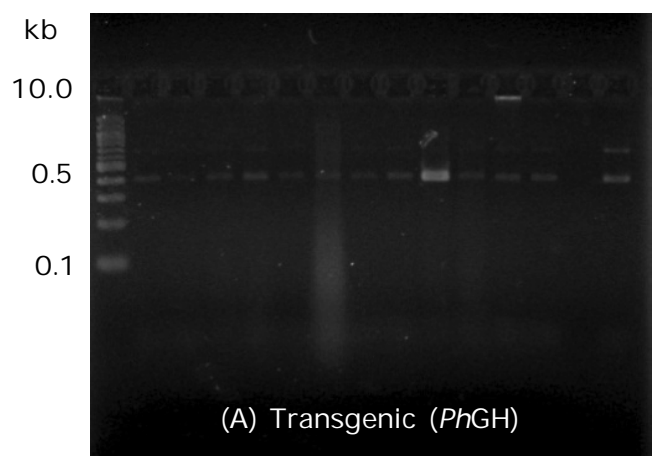

$\begin{array}{lllllllllllllll}M & 1 & 2 & 3 & 4 & 5 & 6 & 7 & 8 & 9 & 10 & 11 & 12 & 13 & 14\end{array}$

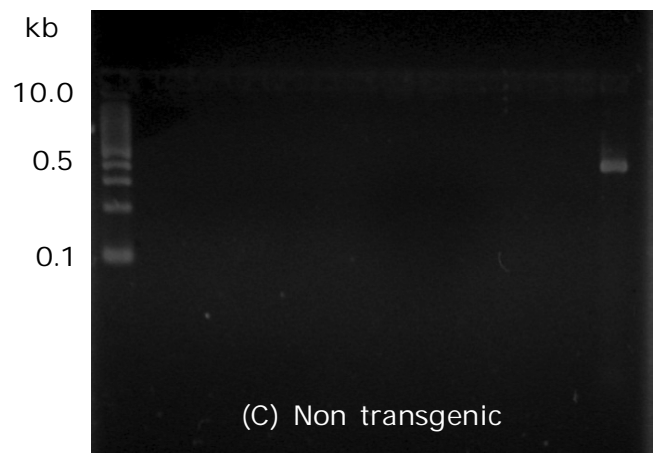

$\begin{array}{lllllllllllllll}M & 1 & 2 & 3 & 4 & 5 & 6 & 7 & 8 & 9 & 10 & 11 & 12 & 13 & 14\end{array}$

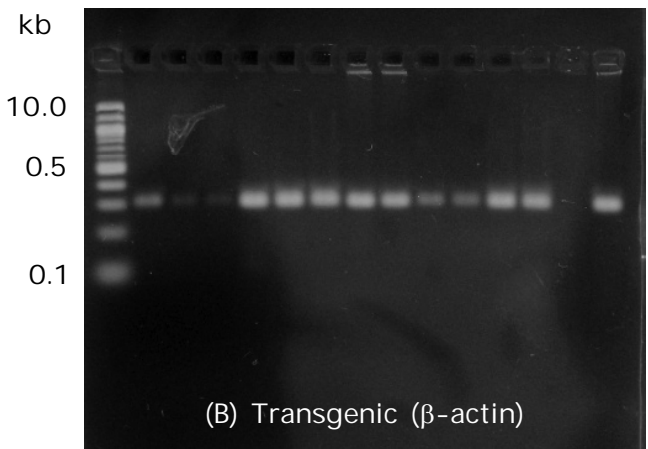

$\begin{array}{lllllllllllllll}M & 1 & 2 & 3 & 4 & 5 & 6 & 7 & 8 & 9 & 10 & 11 & 12 & 13 & 14\end{array}$

$\mathrm{kb}$

10.0

0.5

0.1

(D) Non transgenic ( $\beta$ - actin)

Figure 2. RT- PCR analysis of total RNA in all organs from transgenic African catfish founder $\left(\mathrm{F}_{0}\right)$. Transgenic $(\mathrm{PhGH})(\mathrm{A})$, transgenic $(\beta$ - actin) $(\mathrm{B})$, non transgenic $(\mathrm{C})$, non transgenic $(\beta$ actin), brain (1), pituitary (2), muscle (3), stomach (4), eye (5), gill (6), heart (7), intestine (8), liver (9), spleen (10), kidney (11), caudal fin (12), negative control (13), positive control (14). M indicates a DNA marker (0.1-10.0 kb, Vivantis). The expected size of the amplified fragment was 392 bp. $\beta$ - actin was used as an internal control 

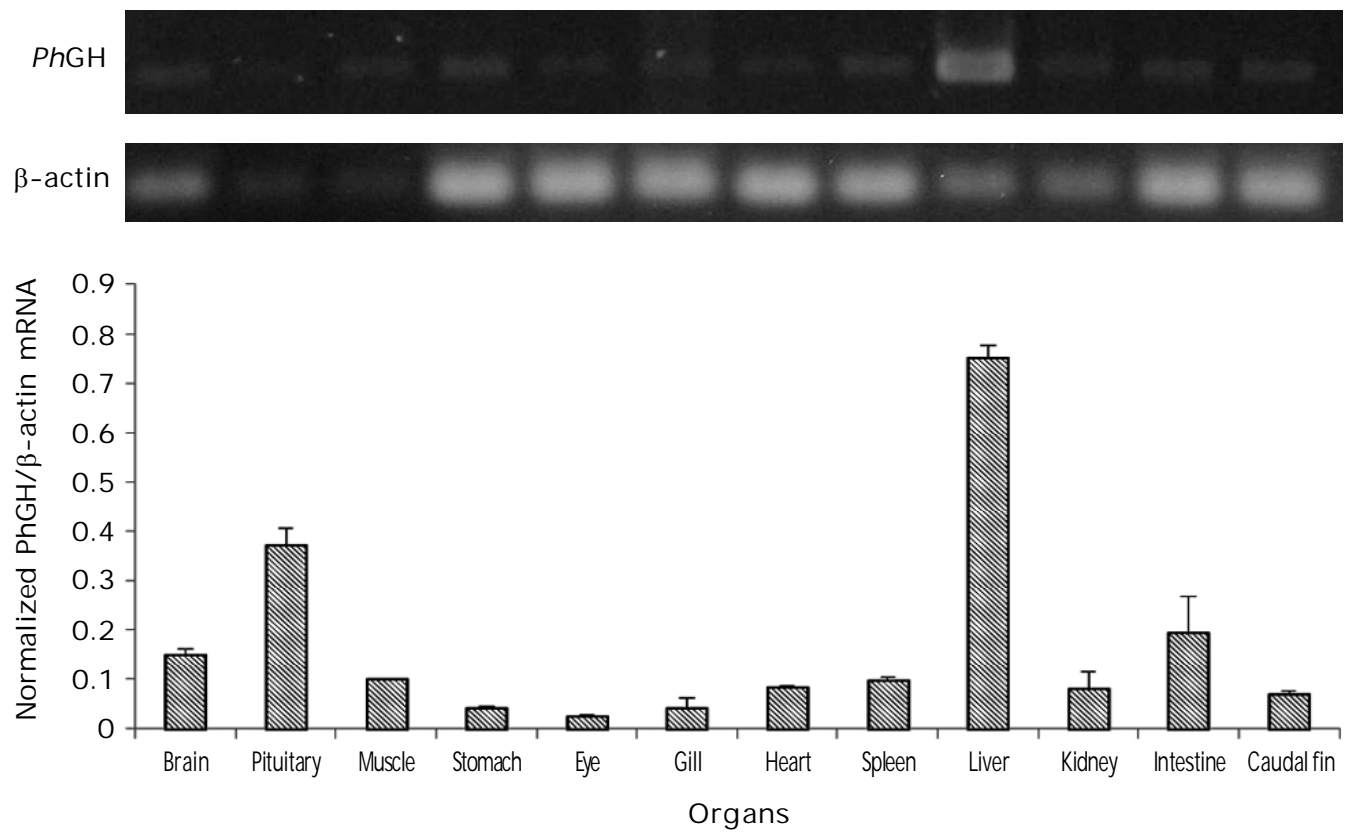

Figure 3. A semiquantitative analysis of RT-PCR in all tissue. Vertical bars represent standard deviation for three fishes

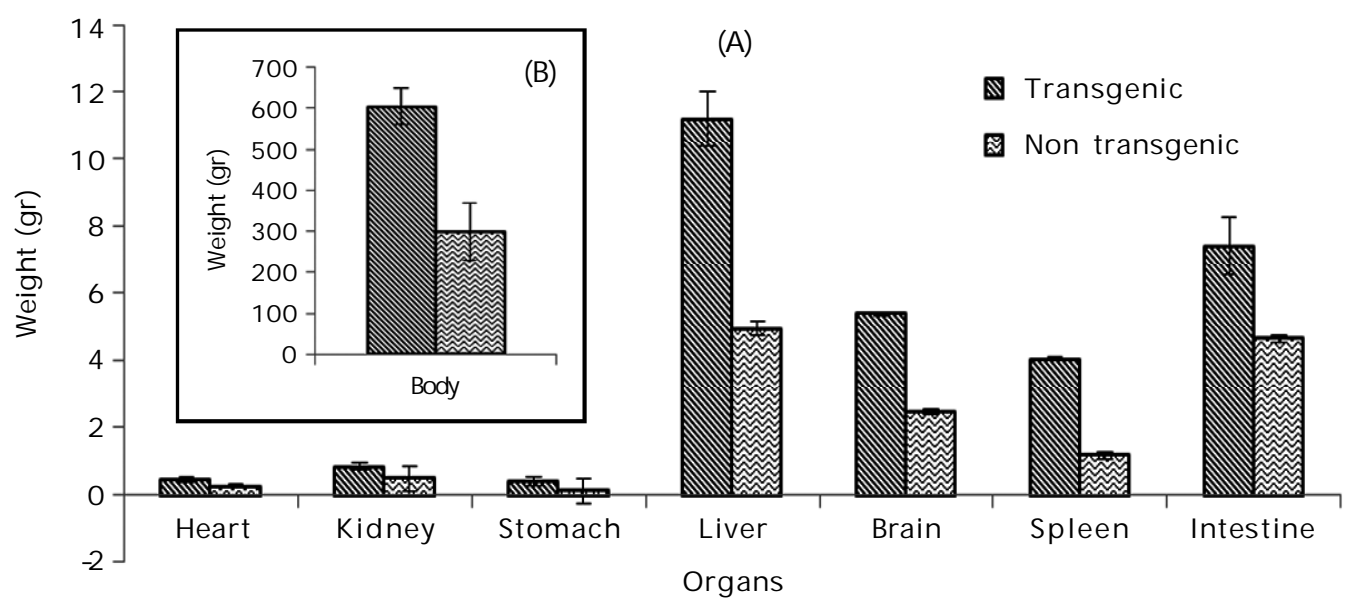

Figure. 4. (A) Several organs and (B) body size between transgenic and non transgenic (control African catfish). Vertical bars represent standard deviation for three fishes

\section{REFERENCES}

Caelers, A., Maclean, N., Hwang, G., Eppler, E., $\&$ Reinecke, M. 2005. Expression of endogenous and exogenous growth hormone (GH) messenger mRNA in a $\mathrm{H}$ - transgenic tilapia (Oreochromis niloticus). Transgenic. Res., 14(1): 95- 104.
Carter, L. 2004. Re- interpreting some common objections to three transgenic applications: GM foods, xenotransplantation and germ line gene modification (GLGM). Transgenic Res., 13: 583- 591.

Devlin, R.H., Yesaki, T.Y., Donaldson, E.M., \& Hew, C.L. 1995. Transmission and pheno- 
typic effects of an antifreeze/GH gene construct in coho salmon (Oncorhynchus kisutch). Aquaculture, 137: 161- 169.

Devlin, R.H., T.Y., Vandersteen, W. E., \&Stevens, E.D. 2012. Genetically modified growth affects allometry of eye and brain in salmonids. Canadian Journal of Zoology, 90(2): 193- 202.

Dewi, R.R.S.P.S., Imron, Marnis, H., \& Suprapto, R. 2011. Produksi Ikan Lele Transgenik Tumbuh Cepat $\left(F_{0}\right)$ Menggunakan Metode Elektroporasi. Laporan Penelitian, Balai Penelitian Pemuliaan Ikan. Sukamandi: Kementerian Kelautan dan Perikanan.

Donaldson, E.M., Fagerlund, U.H.M., Higgs, D.A., \& McBride, J.R. 1979. Hormonal enhancement of growth. In: Hoar, W.S., Randall.D.J., Brett, J.R. (Eds.), Fish Physiology, vol. VIII. Academic Press, New York, p. 455- 597.

Du, S.J., Gong, Z., Fletcher, G.L., Shears, M.A., King, M.J., Idler, D.R., \& Hew, C.L. 1992. Growth enhancement in transgenic Atlantic salmon by the use of an 'all fish' chimeric growth hormone gene construct. Biotechnology, 10: 176- 180.

Figueiredo, M.A., Lanes, C.F.C., \& Almaida, D.V. 2007. Improving the production of transgenic fish germlines: In vivo evaluation of mosaicism in zebrafish (Danio rerio) using a green fluorescent protein (GFP) and growth hormone cDNA transgene co- injection strategy. Genetics and Molecular Biology, 30(1): 31- 36 .

FAO. 2012. Yearbook on fishery statistics. Rome, Italy.

Gibbs, P.D.L. \& Schmale, M.C. 2000. GFP as a marker scorable throughout the life cycle of transgenic zebra fish. Mar. Biotechnol., 2: 107- 125.

Gusrina, Alimuddin, Sumantadinata, K., \& Widyastuti, U. 2009. Transfer gen penyandi hormon pertumbuhan ikan nila (tiGH) pada ikan lele (Clarias sp.) dengan metode mikroinjeksi. J. Ris. Akuakultur, 4(3): 333340.

Kobayashi, S.I., Alimuddin, Morita, T., Endo, M., Takeuchi, T., \& Yoshizaki G. 2007. Transgenic Nile Tilapia (Oreochromis niloticus) over expressing growth hormone show reduced ammonia excretion. Aquaculture, 270: 427- 435.

Laing, K.G., Holland, J., Bonilla, S., Cunningham, C., \& Secombes, C.J. 2001. Cloning and sequencing of caspase 6 in rainbow trout, Oncorhynchus mykiss, and analysis of its expression under conditions known to induce apoptosis. Dev. Comp. Immunol., 25: 303- 312.

Mori, T. \& Devlin, R.H. 1998. Transgene and host growth hormone gene expression in pituitary and nonpituitary tissues of normal and growth hormone transgenic salmon. Mol. Cell. Endocrinol., 149(1999): 129- 139.

Nam, Y.K., Noh, J.K., Cho, Y.S., Cho, H.J., Cho, K.N., Kim, G., \& Kim, D.S. 2001. Dramatically accelerated growth and extraordinary gigantism of transgenic mud loach Misgurnus mizolepis. Trans. Res., 10: 353- 362.

Rahman, M.A. \& Maclean, N. 1992. Production of transgenic tilapia Oreochromis niloticus by one- cell- stage microinjection. Aquaculture, 105: 219- 232.

Rahman, M.A., Mak, R., Ayad, H., Smith, A., \& Maclean, N. 1998. Expression of a novel piscine growth hormone gene results in growth enhancement in transgenic tilapia (Oreochromis niloticus). Transgenic Res., 7: 357- 369.

Sakamoto, T., Shepherd, B.S., Madsen, S.S., Nishioka, R.S., Siharath, K., Richman III, N.H., Bern, H.A., \& Grau, E.G. 1997. Osmoregulatory actions of growth hormone and prolactin in an advanced teleost. Gen. Comp. Endocrinol., 106: 95- 101.

Stuart, G.W., J.V. \& Westerfield, M. 1988. Replication, integration and stable germ- line transmission of foreign sequences injected into early zebrafish embryos. Institute of Neuroscience, University of Oregon, Eugene, OR 97403, USA.

Spadafora, C. 2008. Sperm- mediated 'reverse' gene transfer: a role of reverse transcriptase in the generation of new genetic information. Mini review development reproductiv biologi and medicine. Human Reproduction, 10: 735- 740.

Thermes, V., Grabher, C., Ristoratore, F., Bourrat, F., Choulika, A., Wittbrodt, J., \&Joly, J.S. 2002. I- Scel meganuclease mediates highly efficient transgenesis in fish. Mech. Dev., 18: 91- 98.

Trudeau, V.L. 1997. Neuroendocrine regulation of gonadotrophin II release and gonadal growth in the goldfish, Carassius auratus. Rev. Reprod., 2: 55- 68.

Powers, D.A., Hereford, L., Cole, T., Chen, T.T., Lin, C. M., Knight, K., Creech, K., \& Dunham, R. 1992. Electroporation method for transferring genes into the gametes of zebrafish 
Indonesian Aquaculture Journal Vol.7 No.1, 2012

(Brachydanio rerio), channel catfish (Ictalurus punctatus) and common carp (Cyprinus carpio). Mol. Mar. Biol. Biotechnol., 1:301-308.

Zhang, P., Hayat, M., Joyce, M., GonzalezVillasenor, C., Lin, C.M., Dunham, R.A., Chen, T.T., \& Powers, D.A. 1990. Gene transfer,

expression and inheritance of pRSV- rainbow trout- GH cDNA in the carp, Cyprinus carpio (Linnaeus). Mol. Reprod. Dev., 25: 313.

Zhu, Z.Y. \& Shu, Y.H. 2000. Embryonic and genetic manipulation in fish. Cell Res., 10: 17-27. 